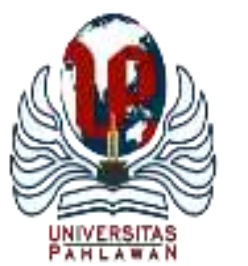

Edukatif : Jurnal Ilmu Pendidikan Volume 4 Nomor 1 Tahun 2022 Halm 827 - 835

EDUKATIF: JURNAL ILMU PENDIDIKAN

Research \& Learning in Education

https://edukatif.org/index.php/edukatif/index

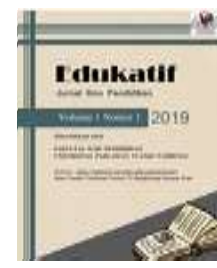

\title{
Persepsi Orang Tua, Guru, dan Siswa Terhadap Pembelajaran Tatap Muka (PTM) Terbatas pada Masa Pandemi Covid-19
}

\author{
Sovi Endah Nurhayati ${ }^{1}$, Nani Ratnaningsih ${ }^{2} \bowtie$ \\ Program Pascasarjana Pendidikan Matematika Universitas Siliwangi, Indonesia ${ }^{1,2}$ \\ E-mail : soviendah9@ gmail.com ${ }^{1}$, naniratnaningsih@unsil.ac.id ${ }^{2}$
}

\begin{abstract}
Abstrak
Penelitian ini bertujuan untuk mengetahui persepsi orang tua, guru dan siswa terhadap pembelajaran tatap muka (PTM) terbatas pada masa pandemi Covid-19. Pengambilan data dalam penelitian ini menggunakan kuesioner dan wawancara. Kuesioner disebar kepada orang tua siswa sebanyak 35 orang, kepada guru sebanyak 25 orang dan kepada siswa sebanyak 35 orang. Penelitian ini dilakukan pada orang tua, guru dan siswa MTs Daarutholibin. Metode penelitian yang digunakan adalah mixed methode yang merupakan gabungan antara kuantitatif dan kualitatif. Dari hasil penelitian diperoleh data orangtua yang menyatakan sangat setuju (8,6\%), setuju $(85,7 \%)$ dan ragu-ragu $(5,7 \%)$. Data yang diperoleh dari guru menyatakan sangat setuju $(84 \%)$ dan setuju (16\%). Sedangkan data yang diperoleh dari siswa menyatakan sangat setuju $(17,1 \%)$, setuju $(74,3 \%)$ dan ragu-ragu $(8,6 \%)$. Dapat disimpulkan bahwa sebagian besar orang tua dan siswa menyatakan setuju sedangkan sebagian besar guru menyatakan sangat setuju dengan pembelajaran tatap muka terbatas pada masa pandemi Covid-19.
\end{abstract}

Kata Kunci: persepsi, pembelajaran tatap muka terbatas, pandemi Covid-19

\begin{abstract}
This study aims to determine the perceptions of parents, teachers and students towards limited face-to-face learning (PTM) during the Covid-19 pandemic. Collecting data in this study using questionnaires and interviews. Questionnaires were distributed to 35 students' parents, 25 teachers and 35 students. This research was conducted on parents, teachers and students of MTs Daarutholibin. The research method used is a mixed method which is a combination of quantitative and qualitative. From the results of the study obtained data from parents who stated strongly agree (8.6\%), agree (85.7\%) and unsure (5.7\%). Data obtained from teachers stated strongly agree (84\%) and agree (16\%). While the data obtained from students stated strongly agree (17.1\%), agree (74.3\%) and uncertain (8.6\%). It can be concluded that most parents and students agree, while most teachers strongly agree with limited face-to-face learning during the Covid-19 pandemic.
\end{abstract}

Keywords: perception, face-to-face learning is limited, Covid-19 pandemic

Copyright (c) 2022 Sovi Endah Nurhayati, Nani Ratnaningsih

$\triangle$ Corresponding author

Email : naniratnaningsih@unsil.ac.id

DOI : https://doi.org/10.31004/edukatif.v4i1.1896

ISSN 2656-8063 (Media Cetak)

ISSN 2656-8071 (Media Online) 
828 Persepsi Orang Tua, Guru, dan Siswa Terhadap Pembelajaran Tatap Muka (PTM) Terbatas pada Masa Pandemi Covid-19 - Sovi Endah Nurhayati, Nani Ratnaningsih

DOI: https://doi.org/10.31004/edukatif.v4i1.1896

\section{PENDAHULUAN}

Peningkatan kasus Covid-19 telah memberikan dampak di berbagai aspek, khususnya dalam aspek pendidikan (Onyema et al., 2020). Dampak Covid-19 terhadap pendidikan dan pembelajaran menimbulkan beberapa peraturan dalam sistem pendidikan yaitu dengan menutup seluruh akses pendidikan secara tatap muka dengan menjalankan prinsip sistem pendidikan dan sistem pembelajaran di sekolah sebagaimana yang sudah ditetapkan oleh pemerintah (Annur \& Maulidi, 2021). Dimulai pada pertengahan Maret 2020 dunia pendidikan melakukan pembelajaran jarak jauh (PJJ) secara daring. Dalam penelitian (Adawiyah et al., 2021) mengatakan bahwa dilaksanakan pembelajaran dengan system daring ini memberikan dampak penurunan pada kualitas pendidikan, menurunnya motivasi belajar siswa, semangat belajar peserta didik menjadi turun, dan terjadi kebosanan dalam pembelajaran dari rumah. Berkaitan dengan hal ini Menteri Pendidikan secara tegas memberikan arahan melalui Surat Edaran No 4 Tahun 2020. Pembelajaran jarak jauh ini memiliki dampak yang beraneka ragam baik bagi orang tua, guru dan siswa. Dalam penelitian (Setyorini, 2020) menyebutkan ada beberapa permasalahan yang dialami oleh orang tua, guru dan siswa dalam kegiatan pembelajaran jarak jauh ini yaitu kurangnya penguasaan dalam tekhnologi, adanya biaya untuk membeli kuota internet, adanya tambahan pekerjaan untuk orang tua dalam mendampingi anak-anaknya belajar, sosialisasi dan komunikasi sesama siswa menurun, orang tua dan guru menjadi berkurang interaksinya dan jam kerja guru seakan tidak ada batasnya.

Meskipun mengalami banyak kendala, namun kegiatan pembelajaran tidak boleh berhenti karena sekolah harus berorientasi pada kebutuhan global yang relevan (Arafah \& Bahri, 2020). Oleh karena itu, diperlukan guru yang inovatif, strategi yang tepat, dan kerja sama kuat antara sekolah dan orang tua untuk menjawab tantangan pendidikan di tengah pandemi Covid-19 ini. Dalam rangka menanggulangi dampak learning loss dan literacy loss yang terjadi selama pandemi Covid-19 di Indonesia, maka dipandang perlu untuk melaksanakan pembelajaran tatap muka (PTM). Namun demikian PTM tersebut harus dilaksanakan secara cermat dan berhati-hati berupa PTM terbatas. (Nissa \& Haryanto, 2020) mengungkapkan bahwa pembelajaran tatap muka merupakan cara pembelajaran klasikal dimana guru dan siswa berkomunikasi secara tatap muka di dalam ruangan atau forum yang sama. Pembelajaran ini memerlukan kehadiran guru dan siswa pada suatu tempat nyata (bukan virtual). Sejalan dengan itu menurut (Anggrawan, 2019) pembelajaran tatap muka merupakan pembelajaran di dalam kelas yang mengandalkan kehadiran pendidik untuk mendidik. Pada pembelajaran tatap muka siswa terlibat dalam komunikasi secara langsung pada lingkungan fisik dan psikis. Berdasarkan uraian di atas, maka pembelajaran tatap muka merupakan suatu proses pembelajaran yang dilakukan dengan komunikasi antar pendidik dan peserta didik secara langsung dalam suatu tempat tanpa adanya perantara media virtual.

Pada tanggal 30 Maret 2021 diterbitkan Surat Keputusan Bersama (SKB) 4 Menteri yakni Menteri Pendidikan dan Kebudayaan, Menteri Agama, Menteri Kesehatan dan Menteri Dalam Negeri Nomor 03/KB/2021, Nomor 384 Tahun 2021, Nomor HK.01.08/ MENKES/4242/2021, Nomor 440-717 Tahun 2021 tentang Panduan Penyelenggaraan Pembelajaran di Masa Pandemi Coronavirus Disease 2019 (COVID-19). Melalui keputusan bersama tersebut, pemerintah mendorong akselerasi pembelajaran tatap muka (PTM) terbatas dengan tetap menjalankan protokol kesehatan yang ketat.

Adapun dasar pertimbangan diterbitkannya SKB 4 ini, yaitu: (1) kesehatan dan keselamatan semua warga satuan pendidikan merupakan prioritas utama yang wajib dipertimbangkan dalam menetapkan kebijakan pembelajaran di masa pandemi; (2) berdasarkan hasil evaluasi Pemerintah, terdapat kebutuhan pembelajaran tatap muka dari peserta didik yang mengalami kendala dalam melaksanakan pembelajaran jarak jauh; (3) sebagai upaya memprioritaskan kesehatan dan keselamatan warga satuan pendidikan, diperlukan intervensi vaksinasi bagi pendidik dan tenaga kependidikan sebagai salah satu upaya percepatan penyelenggaraan pembelajaran tatap muka, selain penerapan protokol kesehatan ketat di satuan pendidikan 
829 Persepsi Orang Tua, Guru, dan Siswa Terhadap Pembelajaran Tatap Muka (PTM) Terbatas pada Masa Pandemi Covid-19 - Sovi Endah Nurhayati, Nani Ratnaningsih

DOI: https://doi.org/10.31004/edukatif.v4i1.1896

dan pertimbangan epidemiologis kasus COVID-19.

Sejak terbitnya Surat Keputusan Bersama 4 menteri tentang Panduan Penyelenggaraan Pembelajaran di Masa Pandemi Coronavirus Disease 2019 (COVID-19) sudah banyak sekolah yang melakukan pembelajaran tatap muka. Proses pembelajaran secara tatap muka terbatas telah dilakukan dari pertengahan bulan Juli 2021 sampai sekarang. Walaupun pembelajaran tatap muka terbatas sudah dilakukan beberapa bulan, tetapi masih ada orang tua, guru dan siswa yang khawatir melakukan pembelajaran tatap muka karena masih adanya klaster Covid-19 di dunia pendidikan. Kekhawatiran ini menimbulkan persepsi yang berbeda antara orang tua, guru dan siswa.

Persepsi sesorang akan berbeda dengan yang lainnya tergantung dengan apa yang dia terima oleh panca inderanya. Persepsi adalah proses yang dijalankan otak untuk menafsirkan informasi sensorik, mengubahnya menjadi gambaran berarti perihal dunia (Nevid, 2017). Sedangkan pengertian persepsi menurut (Perdani, 2018) adalah proses untuk mengartikan sesuatu oleh individu yang diterima melalui penglihatan, perasaan, pendengaran, penciuman dan sentuhan untuk menghasilkan makna dan mengorganisasi serta menginterpretasi masukan-masukan informasi untuk menciptakan gambaran dunia yang mempunyai arti.

Ada beberapa syarat terjadinya persepsi menurut Bimo Walgito (Fentri \& Achnes, 2017) yaitu : (a) Adanya objek yang akan dipersepsi, (b) Adanya panca indera atau reseptor (alat untuk menerima stimulus), (c) Adanya perhatian yang merupakan langkah pertama sebagai persiapan dalam mengadakan persepsi, (d) Persepsi seringkali dinamakan pendapat, sikap, penilaian. Persepsi diartikan proses yang berujung ke pusat susunan syaraf yaitu otak sehingga individu tersebut menyadari apa yang dilihat, apa yang didengar. Sebab itu proses penginderaan akan selalu terjadi pada waktu individu menerima stimulus. Aspek-aspek persepsi menurut Bimo Walgito (Fentri \& Achnes, 2017) yaitu : (a) Aspek kognitif, komponen ini tersusun atas dasar pengetahuan yang dimiliki seseorang mengenai objek. Berkaitan dengan pikiran seseorang apa yang ada dalam pikiran orang itu. Kognitif bersifat rasional, masuk akal. (b) Aspek afektif, komponen afektif berhubungan dengan rasa senang dan rasa tidak senang, jadi sifatnya evaluative yang berhubungan erat dengan nilai-nilai kebudayaan atau sistem nilai yang dimilikinya. Berkaitan dengan perasaan, bersifat emosional. Wujudnya bisa berupa perasaan senang, sedih, ceria, dan gembira. (c) Aspek konatif, komponen konatif merupakan kesiapan seseorang utntuk bertingkah laku yang berhubungan dengan objek sikapnya, berkaitan dengan tindakan, wujudnya adalah tindakan seseorang terhadap objeknya.

Pada penelitian sebelumnya yang dilakukan oleh (Sabiq, 2020) dengan judul "Persepsi Orang Tua Siswa tentang Pembelajaran Tatap Muka pada Era New Normal Pandemi Covid-19" dari hasil penelitiannya diperoleh bahwa orang tua yang menyatakan setuju (74,5\%), tidak setuju $(8,2 \%)$, dan ragu-ragu $(17,3 \%)$ tentang pembelajaran tatap muka pada era new normal pandemi Covid-19. Sejalan dengan penelitian (Pranatawijaya et al., 2019) yang berjudul "Analisis Persetujuan Orang Tua Terhadap Rencana Pembelajaran Tatap Muka Terbatas Di Smk Santa Maria Jakarta” yang menyebutkan 72,2\% (250 responden) orang tua setuju dengan kebijakan pembelajaran tatap muka terbatas dari pemerintah dan sebanyak $29,8 \%$ (106 responden) orang tua tidak menyetujui mengenai kebijakan pembelajaran tatap muka terbatas. Dari dua penelitian tersebut sebagian besar orang tua menyatakan setuju dengan adanya pembelajaran tatap muka di masa pandemi Covid-19.

Tidak hanya orang tua saja yang menginginkan anaknya cepat kembali melakukan pembelajaran tatap muka di sekolah, namun guru dan siswa juga menginginkan hal yang sama. Hal ini sejalan dengan penelitian yang dilakukan oleh (Sabiq, 2020) ia mengatakan di satu sisi orang tua berharap anaknya bisa berangkat sekolah karena ada banyak masalah atau kendala dalam pembelajaran online, namun guru juga ingin mengajar peserta didiknya secara langsung agar bisa maksimal, dan anak-anak sudah mulai jenuh belajar dari rumah.

Pembelajaran tatap muka di masa pandemi masih menjadi kontroversi salah satu penyebabnya karena tingkat kepatuhan masyarakat terhadap protokol kesehatan masih sangat rendah. Hal ini sesuai dengan hasil penelitian dari (Simanjuntak et al., 2020) yang menemukan bahwa individu berusia diatas 60 tahun lebih 
830 Persepsi Orang Tua, Guru, dan Siswa Terhadap Pembelajaran Tatap Muka (PTM) Terbatas pada Masa Pandemi Covid-19 - Sovi Endah Nurhayati, Nani Ratnaningsih

DOI: https://doi.org/10.31004/edukatif.v4i1.1896

patuh terhadap protokol kesehatan yakni sebanyak $80 \%$. Sementara orang dewasa dan anak-anak usia sekolah masih lalai dalam menerapkan protokol kesehatan seperti menggunakan masker, dan mencuci tangan.

Selain tanggapan dari orang tua mengenai proses pembelajaran tatap muka, tanggapan dari guru tidak kalah penting, karena proses pembelajaran tidak akan berjalan dengan baik tanpa adanya guru. Pembelajaran tatap muka terbatas pada masa pandemi disambut baik oleh guru alasannya karena banyaknya kendala pada pembelajaran daring. Hasil penelitian (Sutia \& Sagita, 2020) mengungkapkan terdapat beberapa kendala yang dialami oleh guru dan siswa pada saat pelaksanaan pembelajaran daring yaitu terkait akses dan kuota internet, sekolah perlu memberi dukungan kepada guru dan siswa terutama dalam penyediaan akses internet, baik siswa dan guru merindukan kegiatan pembelajaran tatap muka secara langsung.

Siswa merupakan aspek utama yang akan melakukan pembelajaran tatap muka, oleh karena itu tanggapan siswa terhadap pembelajaran tatap muka terbatas di masa pandemi menjadi hal yang penting. Banyak siswa yang sudah merasa bosan belajar online karena tidak bisa berinteraksi langsung dengan guru dan teman-temannya. Hal ini sejalan dengan hasil penelitian (Kusuma \& Sutapa, 2020) yang mengemukakan dampak negatif pembelajaran online diantranya menunjukan dampak perilaku sosial emosional anak antara lain kurangnya sikap kooperatif, toleransi, dan terkadang merasa bosan dan sedih, serta merindukan teman dan gurunya. Penelitian ini menjadi penting karena diharapkan bisa menjadi bagian dari sumber pengambilan keputusan bagi pihak terkait, khususnya bagi orang tua, guru, siswa, sekolah dan umumnya untuk masyarakat luas mengenai kebiasaan baru yaitu melakukan pembelajaran tatap muka terbatas di masa pandemi.

Berdasarkan uraian di atas rumusan masalah dari penelitian ini adalah untuk mengetahui bagaimana persepsi orang tua, guru dan siswa terhadap pembelajaran tatap muka (PTM) terbatas pada masa pandemi Covid-19. Tujuan dari penelitian ini adalah untuk mengetahui persepsi orang tua, guru dan siswa terhadap pembelajaran tatap muka (PTM) terbatas pada masa pandemi Covid-19.

\section{METODE PENELITIAN}

Metode yang digunakan dalam penelitian ini adalah mixed method yang bertujuan untuk mendeskripsikan persepsi orang tua, guru dan siswa terhadap pembelajaran tatap muka terbatas pada masa pandemi Covid-19. (Creswell \& Creswell, 2017) mengemukakan mixed method merupakan metode penelitian yang mengkombinasikan antara kualitatif dan kuantitatif.

Populasi dalam penelitian ini orang tua, guru dan siswa MTs Daarutholibin. Adapun sampel dalam penelitian ini adalah orang tua siswa kelas IX sebanyak 35 orang, guru sebanyak 25 orang dan siswa kelas IX sebanyak 35 orang. Pengambilan responden dalam penelitian ini dilakukan dengan teknik purposive sampling dimana peneliti menentukan sendiri partisipan berdasarkan tujuan penelitian. Penelitian ini dilakukan di sekolah MTs Daarutholibin tahun ajaran 2021/2022 pada bulan Oktober 2021. Adapun alasan pemilihan sekolah tersebut karena MTs tersebut merupakan salah satu lembaga yang berbasis pondok pesantren dan sudah melakukan pembelajaran tatap muka lebih awal di banding sekolah lain yang berada di sekitar wilayah tersebut.

Adapun tekhnik pengumpulan data dalam penelitian ini dengan menggunakan kuesioner dan wawancara. Instrumen kuesioner di buat dengan mengembangkan teori. Kuesioner tersebut di susun kemudian disebar kepada seluruh responden. Teknik analisis data dalam penelitian ini menggunakan skala model Likert. Jawaban setiap item instrumen yang menggunakan skala Likert dapat berupa kata-kata antara lain: sangat setuju (SS), setuju (ST), raguragu (R), tidak setuju (TS) dan sangat tidak setuju (STS) (Mawardi, 2019). Dalam skala Likert, terdapat dua bentuk pertanyaan yaitu bentuk pertanyaan positif yang mengukur skala positif dengan skor dari 5, 4, 3, 2 dan 1. Sedangkan bentuk pertanyaan negatif digunakan untuk mengukur skala negatif yang diberi skor 1, 2, 3, 4 dan 5 (Pranatawijaya et al., 2019). 
831 Persepsi Orang Tua, Guru, dan Siswa Terhadap Pembelajaran Tatap Muka (PTM) Terbatas pada Masa Pandemi Covid-19 - Sovi Endah Nurhayati, Nani Ratnaningsih

DOI: https://doi.org/10.31004/edukatif.v4i1.1896

Selanjutnya dari jawaban responden terhadap setiap pernyataan akan diperoleh distribusi frekuensi respon bagi setiap kategori jawaban, yang kemudian secara komulatif akan dilihat deviasinya menurut distribusi normal. Dari sinilah nilai skala dapat ditentukan. Selanjutnya nilai skala ini merupakan bobot atau skor terhadap jawaban subyek secara individual. Kemudian dilakukan juga wawancara terhadap responden. Wawancara yang dilakukan adalah wawancara tidak terstruktur. Wawancara ini dilakukan kepada sampel yang dalam mengisi kuesioner mempunyai peluang untuk ditindaklanjuti dengan wawancara. Wawancara dilakukan kepada 2 orang tua siswa dan 3 siswa, ini mengacu pada hasil pengolahan data kuesioner dengan skor paling kecil terhadap jawaban subyek.

\section{HASIL DAN PEMBAHASAN PENELITIAN}

Beragam respon disampaikan oleh orang tua, guru dan siswa mengenai pembelajaran tatap muka terbatas di masa pandemi ini. Berdasarkan dari hasil data yang diisi oleh orang tua, guru dan siswa terkait pendapat mereka mengenai pembelajaran tatap muka terbatas pada masa pandemi. Dari data yang diperoleh, terdapat lima pilihan jawaban, yaitu Sangat Setuju (SS), Setuju (S), Ragu-ragu (R), Tidak Setuju (TS), dan Sangat Tidak Setuju (STS) sebagaimana disajikan dalam tabel berikut :

\section{A. Hasil Analisis Data Pernyataan Orang Tua}

Tabel 1. Persepsi Orang Tua

\begin{tabular}{ccccc}
\hline \multicolumn{5}{c}{ Persepsi orang tua terhadap PTM terbatas secara keseluruhan } \\
\hline Kategori & Interval & $\%$ & F & $\%$ \\
\hline SS & $75-90$ & $\geq 83$ & 3 & 8,6 \\
\hline S & $61-74$ & $68-82$ & 30 & 85,7 \\
\hline R & $47-60$ & $52-67$ & 2 & 5,7 \\
\hline TS & $33-46$ & $37-51$ & - & - \\
\hline STS & $18-32$ & $\leq 36$ & - & - \\
\hline \multicolumn{3}{c}{ Persepsi orang tua terhadap PTM terbatas berdasarkan sub variabel } \\
\hline \multicolumn{3}{c}{ Aspek Kognitif } & \multicolumn{3}{c}{$69,6 \%$} \\
\hline Aspek Afektif & & $79 \%$ \\
\hline & Asfek konatif & $9,8 \%$ \\
\hline
\end{tabular}

Dari tabel 1, diketahui persepsi orang tua terhadap PTM terbatas pada masa pandemi secara umum berada pada kategori Setuju dengan jumlah 30 orang tua $(85,7 \%)$. Selain itu, terdapat 3 orang tua yang memiliki persepsi pada kategori Sangat Setuju $(8,6 \%)$. Hasil analisis juga menunjukan bahwa 2 orang tua memiliki persepsi pada kategori Ragu-ragu $(5,7 \%)$ serta tidak ada orang tua yang memiliki persepsi pada kategori Tidak Setuju dan Sangat Tidak Setuju. Kemudian hasil pendistribusian instrumen menunjukan bahwa orang tua cenderung memiliki persepsi pada aspek afektif sebesar 79\%, kemudian pada aspek kognitif 69,6\% dan pada aspek konatif sebesar 9,8\%.

Sejalan dengan hasil penelitian diparagraf sebelumnya maka hasil penelitian menunjukan bahwa persepsi orang tua memiliki sedikit kesamaan terhadap pembelajaran tatap muka terbatas. Dalam penelitian ini persepsi orang tua dengan kategori Setuju memiliki persentase yang sangat besar, hal ini sama dengan dua penelitian sebelumnya. Sedangkan di dalam penelitian ini tidak ada orang tua yang memiliki persepsi Tidak Setuju. Dapat disimpulkan bahwa sebagian besar orang tua menyatakan Setuju terhadap pembelajaran tatap muka pada masa pandemi Covid-19. Hal ini dikarenakan sebagian besar orang tua selalu menjaga protokol kesehatan baik di rumah maupun di luar rumah.

Pada wawancara yang dilakukan kepada 2 orang tua siswa yang menyatakan masih ragu-ragu terhadap pembelajaran tatap muka terbatas, alasannya dikarenakan orang tua tidak bisa memastikan apakah anak di 
832 Persepsi Orang Tua, Guru, dan Siswa Terhadap Pembelajaran Tatap Muka (PTM) Terbatas pada Masa Pandemi Covid-19 - Sovi Endah Nurhayati, Nani Ratnaningsih

DOI: https://doi.org/10.31004/edukatif.v4i1.1896

sekolah mematuhi protokol kesehatan atau tidak. Selain itu orang tua yang khawatir jika anaknya melakukan pembelajaran tatap muka karena masih terdapat klaster Covid-19 di dunia pendidikan. Hal ini sejalan dengan penelitian (Meghani et al., 2021) yang menemukan bahwa hampir sepertiga orang tua di Amerika Serikat keberatan untuk mengembalikan anak-anak mereka ke sekolah meskipun PJJ yang dilakukan mengalami banyak tantangan. Mereka masih belum merasa aman mengizinkan anak mereka mengikuti pembelajaran tatap muka karena melihat tingkat penyebaran kasus Covid-19 yang tinggi dan juga sekolah belum memberikan informasi akurat terkait praktik keamanan dan penanganan terhadap Covid-19.

\section{B. Hasil Analisis Data Pernyataan Guru}

Tabel 2. Persepsi Guru

\begin{tabular}{ccccc}
\hline \multicolumn{5}{c}{ Persepsi guru terhadap PTM terbatas secara keseluruhan } \\
\hline Kategori & Interval & $\%$ & F & $\%$ \\
\hline SS & $75-90$ & $\geq 83$ & 21 & 84 \\
\hline S & $61-74$ & $68-82$ & 4 & 16 \\
\hline R & $47-60$ & $52-67$ & - & - \\
\hline TS & $33-46$ & $37-51$ & - & - \\
\hline STS & $18-32$ & $\leq 36$ & - & - \\
\hline \multicolumn{5}{c}{ Persepsi guru terhadap PTM terbatas berdasarkan sub variabel } \\
\hline \multicolumn{3}{c}{ Aspek Kognitif } & \multicolumn{3}{c}{$89,7 \%$} \\
\hline Aspek Afektif & & $86,3 \%$ \\
\hline Aspek Konatif & & $88 \%$ \\
\hline
\end{tabular}

Dari tabel 2, diketahui persepsi guru terhadap PTM terbatas pada masa pandemi secara umum berada pada kategori Sangat Setuju dengan jumlah 21 guru (84\%). Hasil analisis juga menunjukan bahwa 4 guru memiliki persepsi pada kategori Setuju sebesar (16\%) serta tidak ada guru yang memiliki persepsi pada kategori Ragu-ragu, Tidak Setuju dan Sangat Tidak Setuju. Kemudian hasil pendistribusian instrumen menunjukan bahwa guru cenderung memiliki persepsi pada aspek kognitif sebesar $89,7 \%$, kemudian pada aspek konatif $88 \%$ dan pada aspek afektif sebesar $86,3 \%$.

Dapat disimpulkan bahwa sebagian besar guru menyatakan Sangat Setuju terhadap pembelajaran tatap muka pada masa pandemi Covid-19. Dan tidak ada permasalahan pada persepsi guru terhadap PTM terbatas, karena guru sudah mengetahui, melakukan dan mengaplikasikan hal-hal yang ada pada pernyataan kuesioner.

\section{Hasil Analis Data Pernyataan Siswa}

Tabel 3. Pernyataan Siswa

\begin{tabular}{ccccc}
\hline \multicolumn{5}{c}{ Persepsi siswa terhadap PTM } \\
\hline Kategori & Interval & $\%$ & F & $\%$ \\
\hline SS & $75-90$ & $\geq 83$ & 6 & 17,1 \\
\hline S & $61-74$ & $68-82$ & 26 & 74,3 \\
\hline R & $47-60$ & $52-67$ & 3 & 8,6 \\
\hline TS & $33-46$ & $37-51$ & - & - \\
\hline STS & $18-32$ & $\leq 36$ & - & - \\
\hline \multicolumn{7}{c}{} & $\sum$ & & 35 & 100 \\
\hline
\end{tabular}

Persepsi siswa terhadap PTM terbatas berdasarkan sub variabel

\begin{tabular}{cc}
\hline Aspek Kognitif & $74 \%$ \\
\hline Aspek Afektif & $79 \%$ \\
\hline Aspek Konatif & $75,2 \%$ \\
\hline
\end{tabular}


833 Persepsi Orang Tua, Guru, dan Siswa Terhadap Pembelajaran Tatap Muka (PTM) Terbatas pada Masa Pandemi Covid-19 - Sovi Endah Nurhayati, Nani Ratnaningsih

DOI: https://doi.org/10.31004/edukatif.v4i1.1896

Dari tabel 3, diketahui persepsi siswa terhadap PTM terbatas pada masa pandemi secara umum berada pada kategori Setuju dengan jumlah 26 siswa $(74,3 \%)$. Selain itu, terdapat 6 siswa yang memiliki persepsi pada kategori Sangat Setuju (17,1\%). Hasil analisis juga menunjukan bahwa 3 siswa memiliki persepsi pada kategori Ragu-ragu $(8,6 \%)$ serta tidak ada siswa yang memiliki persepsi pada kategori Tidak Setuju dan Sangat Tidak Setuju. Kemudian hasil pendistribusian instrumen menunjukan bahwa orang tua cenderung memiliki persepsi pada aspek afektif sebesar 79\%, kemudian pada aspek konatif 75,2\% dan pada aspek kognitif sebesar $74 \%$.

Dapat disimpulkan bahwa sebagian besar siswa menyatakan Setuju terhadap pembelajaran tatap muka pada masa pandemi Covid-19. Hal ini dikarenakan sebagian besar siswa sudah merindukan suasana belajar tatap muka. Pada wawancara yang dilakukan kepada 3 siswa yang menyatakan masih ragu-ragu terhadap pembelajaran tatap muka terbatas, alasannya dikarenakan takut tertular Covid-19 ketika proses pembelajaran berlangsung karena sebagian orang yang terkena Covid tidak menunjukan gejala. Dalam penelitian (Anggraini et al., 2021) menyatakan bahwa covid-19 ialah jenis virus dengan tingkat penularan yang cukup kilat, dimana virus itu dapat menular dengan melalui udara maupun setuhan.

Hal-hal yang menjadi ketakutan orang tua dan siswa adalah PR besar baik bagi pemerintah maupun penyelenggara pendidikan. Ini dikarenakan masih kurangnya informasi dari sekolah kepada orang tua dan siswa terkait prosedur dan syarat-syarat apa saja yang harus dipenuhi ketika pembelajaran tatap muka terbatas pada masa Covid-19 akan dilaksanakan. Badan pemerintah seperti contohnya sekolah, dapat memanfaatkan media sosial agar dapat berinteraksi dengan para pemangku kepentingan, walaupun terdapat tantangan terkait dengan privasi, keamanan, pengelolaan data, aksesibilitas, inklusi sosial, tata kelola, dan masalah kebijakan informasi lainnya (Pratiwi \& Aslam, 2021). Langkah-langkah lain yang bisa dilakukan kepala sekolah menurut (Kemendikbud, 2021) adalah : (a) Konsisten memberikan edukasi tentang penerapan protokol kesehatan dalam upaya membangun budaya disiplin, (b) Memastikan seluruh pembelajaran tatap muka terbatas berlangsung sesuai protokol kesehatan, (c) Menyiapkan satgas Covid-19 di sekolah, (d) Diperlukan penanganan khusus. Jika ditemukan kasus terkonfirmasi Covid-19, pembelajaran tatap muka terbatas dapat ditutup sementara.

\section{KESIMPULAN}

Dari hasil penelitian mengenai persepsi orang tua, guru dan siswa terhadap PTM terbatas diperoleh data orang tua yang menyatakan sangat setuju $(8,6 \%)$, setuju $(85,7 \%)$ dan ragu-ragu $(5,7 \%)$. Data yang diperoleh dari guru menyatakan sangat setuju (84\%) dan setuju (16\%). Sedangkan data yang diperoleh dari siswa menyatakan sangat setuju $(17,1 \%)$, setuju $(74,3 \%)$ dan ragu-ragu $(8,6 \%)$. Dapat disimpulkan bahwa sebagian besar orang tua dan siswa menyatakan setuju sedangkan sebagian besar guru menyatakan sangat setuju dengan pembelajaran tatap muka terbatas pada masa pandemi Covid-19.

\section{UCAPAN TERIMA KASIH}

Pelaksanaan penelitian ini tidak terlepas dari bantuan atau bimbingan dari berbagai pihak. Penulis mengucapkan terima kasih kepada kepala sekolah MTs Daarutholibin yang telah memberikan izin kepada penulis untuk melakukan penelitian di sekolah yang beliau pimpin. Terima kasih juga kepada orang tua siswa, guru dan siswa MTs Daarutholibin yang telah ikut berpartisipasi dan kepada pihak-pihak lain yang telah membantu atau memberikan dukungan baik berupa dukungan moril atau materil demi kelancaran kegiatan penelitian ini. 
834 Persepsi Orang Tua, Guru, dan Siswa Terhadap Pembelajaran Tatap Muka (PTM) Terbatas pada Masa Pandemi Covid-19 - Sovi Endah Nurhayati, Nani Ratnaningsih

DOI: https://doi.org/10.31004/edukatif.v4i1.1896

\section{DAFTAR PUSTAKA}

Adawiyah, R., Isnaini, N. F., Hasanah, U., \& Faridah, N. R. (2021). Kesiapan Pelaksanaan Pembelajaran Tatap Muka Pada Era New Normal Di Mi At-Tanwir Bojonegoro. Jurnal Basicedu, 5(5), 3814-3821.

Anggraini, M., Kasiyun, S., \& Mariati, P. (2021). Analisis Keberhasilan Peserta Didik Dalam Pembelajaran Tematik Melalui Daring Pada Masa Pandemi Covid-19 Di Sekolah Dasar. Jurnal Basicedu: Journal Of Elementary Education, 5(5), 3010-3019.

Anggrawan, A. (2019). Analisis Deskriptif Hasil Belajar Pembelajaran Tatap Muka Dan Pembelajaran Online Menurut Gaya Belajar Mahasiswa. Matrik: Jurnal Manajemen, Teknik Informatika Dan Rekayasa Komputer, 339-346.

Annur, F., \& Maulidi, A. (2021). Pembelajaran Tatap Muka Di Tengah Pandemi Covid-19: Studi Kasus Pada Madrasah Aliyah Nurul Huda Pekandangan Barat. Maharot: Journal Of Islamic Education, 5(1), 17-36.

Arafah, N., \& Bahri, S. (2020). Peningkatan Human Capital Dalam Proses Pembelajaran Di Era New Normal. Jurnal Manajemen Bisnis, 17(3), 425-444.

Creswell, J. W., \& Creswell, J. D. (2017). Research Design: Qualitative, Quantitative, And Mixed Methods Approaches. Sage Publications.

Fentri, D. M., \& Achnes, S. (2017). Persepsi Pengunjung Terhadap Daya Tarik Taman Wisata Alam Hutan Rimbo Tujuh Danau Di Desa Wisata Buluh Cina Kecamatan Siak Hulu Kabupaten Kampar Riau. Riau University.

Kemendikbud. (2021). No Title. Keputusan Bersama Menteri Pendidikan Dan Kebudayaan, Menteri Agama, Menteri Kesehatan, Dan Menterti Dalam Negeri Tentang Panduan Penyelenggaraan Pembelajaran Di Masa Pandemi Coronavirus Disease 2019 (Covid-19).

Kusuma, W. S., \& Sutapa, P. (2020). Dampak Pembelajaran Daring Terhadap Perilaku Sosial Emosional Anak. Jurnal Obsesi: Jurnal Pendidikan Anak Usia Dini, 5(2), 1635-1643.

Mawardi, M. (2019). Rambu-Rambu Penyusunan Skala Sikap Model Likert Untuk Mengukur Sikap Siswa. Scholaria: Jurnal Pendidikan Dan Kebudayaan, 9(3), 292-304.

Meghani, A., Agarwal, S., Zapf, A. J., Edwards, J., Labrique, A. B., \& Gibson, D. G. (2021). Schooling Amidst A Pandemic: Parents' Perceptions About Reopening Schools And Anticipated Challenges During Covid-19. Medrxiv.

Nevid, J. S. (2017). Psikologi Konsepsi Dan Aplikasi. Bandung: Nusa Media.

Nissa, S. F., \& Haryanto, A. (2020). Implementasi Pembelajaran Tatap Muka Di Masa Pandemi Covid-19. Jurnal Ika Pgsd (Ikatan Alumni Pgsd) Unars, 8(2), 402-409.

Onyema, E. M., Eucheria, N. C., Obafemi, F. A., Sen, S., Atonye, F. G., Sharma, A., \& Alsayed, A. O. (2020). Impact Of Coronavirus Pandemic On Education. Journal Of Education And Practice, 11(13), 108-121.

Perdani, N. M. P. (2018). Persepsi Mahasiswa Jurusan Administrasi Bisnis Polsri Terhadap Minat Membaca Surat Kabar Halaman Zetizen Sumatera Ekspres. Politeknik Negeri Sriwijaya.

Pranatawijaya, V. H., Widiatry, W., Priskila, R., \& Putra, P. B. A. A. (2019). Penerapan Skala Likert Dan Skala Dikotomi Pada Kuesioner Online. Jurnal Sains Dan Informatika, 5(2), 128-137.

Pratiwi, N., \& Aslam, A. (2021). Pengaruh Model Pembelajaran Picture And Picture Terhadap Kemampuan Berpikir Kreatif Siswa Di Sekolah Dasar. Edukatif: Jurnal Ilmu Pendidikan, 3(6), 3697-3703.

Sabiq, A. F. (2020). Persepsi Orang Tua Siswa Tentang Pembelajaran Tatap Muka Pada Era New Normal Pandemi Covid-19. Journal Of Islamic Education Research, 1(3), 179-189.

Setyorini, I. (2020). Pandemi Covid-19 Dan Online Learning: Apakah Berpengaruh Terhadap Proses Pembelajaran Pada Kurikulum 13? Journal Of Industrial Engineering \& Management Research, 1(1), 95-102. 
835 Persepsi Orang Tua, Guru, dan Siswa Terhadap Pembelajaran Tatap Muka (PTM) Terbatas pada Masa Pandemi Covid-19 - Sovi Endah Nurhayati, Nani Ratnaningsih

DOI: https://doi.org/10.31004/edukatif.v4i1.1896

Simanjuntak, D. R., Napitupulu, T. M., Wele, A. M., \& Yanie, R. (2020). Gambaran Kepatuhan Masyarakat Menerapkan Protokol Kesehatan Covid-19 Di Tempat Umum Periode September 2020 Di Dki Jakarta.

Sutia, C., \& Sagita, S. (2020). Tanggapan Siswa, Orang Tua Dan Guru Terhadap Pembelajaran Jarak Jauh Selama Pandemi Covid-19 (Students, Parents And Teachers' Responses To Distance Learning During The Covid-19 Pandemic). Jurnal Inspirasi, 11(2), 156-165. 